\title{
A SPATIAL AND TEMPORAL ANALYSIS OF LAND USE CHANGES IN TWO MOUNTAIN VALLEYS: WITH AND WITHOUT DAM RESERVOIR (POLISH CARPATHIANS)
}

\author{
Łukasz Wiejaczka ${ }^{1}$, Jan Romuald Olędzki², Anna BucaŁa-Hrabia ${ }^{1}$, \\ MaŁgorzata KijowsKa-STrugaŁA ${ }^{3}$
}

\begin{abstract}
${ }^{1}$ Institute of Geography and Spatial Organization Polish Academy of Sciences, Kraków, Poland ${ }^{2}$ Department of Geomatics and Cartography, Faculty of Earth Sciences, Nicolaus Copernicus University, Torun, Poland

${ }^{3}$ Institute of Geography and Spatial Organization Polish Academy of Sciences, Szymbark, Poland
\end{abstract}

Manuscript received: August 19, 2016

Revised version: February 28, 2017

\begin{abstract}
Wiejaczka Ł, Olęidzi J.R., BucaŁa A., Kijowska-StrugaŁa M. 2017. A spatial and temporal analysis of land use changes in two mountain valleys: with and without dam reservoir (Polish Carpathians). Quaestiones Geographicae 36(1), Bogucki Wydawnictwo Naukowe, Poznań, pp. 129-137, 5 figs, 4 tables.

AвSTRACT: This study analyzed the temporal and spatial changes in land use taking place in two adjacent river valleys, located within the Polish Carpathians. The land use in 1977 and 2009 was presented for selected areas. In one of the valleys, a dam has been operating since 1994 along with a retention reservoir, which is an additional factor influencing the direction and scale of the land use changes. An analysis using GIS techniques showed that the general directions of transformation in both valleys in the land use structure are similar but with different intensity. In studied valleys a decrease of area with agricultural land and gradual increase in the forested area have been observed. In the valley with the reservoir few more changes were noticed. The decrease of the forested area by $5.5 \%$ and farmland by $8.2 \%$ on the areas submerged by reservoir was observed. The strip fields pattern has been changed into more dispersed. The road network development was also observed, as well as the change of nature of residential/agricultural buildings into residential/recreational.
\end{abstract}

KEY WORDS: land use changes, mountain valleys, dam reservoir, Carpathians

Corresponding author: abucala@zg.pan.krakow.pl

\section{Introduction}

The socio-economic transformations taking place in the Polish Carpathians in recent decades have led to significant changes in the structure of land use. One of the manifestations of these changes is a gradual decrease in the arable land due to the declining profitability of traditional farming in the mountains and an increase in forest areas (e.g. Kozak 2003, Szwagrzyk 2004, Dec et al. 2009, Kaim 2009, Ostafin 2009, Bucała et al. 2015, Kijowska-Strugała 2015, KijowskaStrugała, Demczuk 2015). The changes occurring in the Polish Carpathians correspond with an earlier trend found in other mountainous regions in Europe, namely the declining proportion of cultivated land and the increasing area of forests (eg. Bätzing et al. 1996, MacDonald et al. 2000, Lipský 2001, Falcucci et al. 2007). In addition to general socio-economic transformations, changes in the structure of local land use are compounded by additional factors, e.g. the construction of dams. 
The creation of a dam and reservoir is human intervention in the natural environment, causing, among other things: changes in the hydrological regime of the river, riparian ecosystems, the channel and valley morphology, the biodiversity of river species and water quality (e.g. Magilligan, Nislow 2005, Nilsson, Berggren 2000, Petts, Gurnell 2005, Power et al. 1996, Graf 2006, Wei et al. 2009, Soja, Wiejaczka 2014). Significant changes related to the operation of reservoirs also occur in the structure of land use in the immediate vicinity (e.g. Vandeveer, Drummond 1976, Tefera, Sterk 2008, Cao et al. 2011, Woldemichael et al. 2012, Pilgrim 2014). The immediate effect observed after dam construction is that the landscape is instantly filled with the reservoir water (Woldemichael et al. 2012). Research into the changes in land use around the reservoirs (in the literature cited above) in different areas of the world show a general increase of nonagricultural land use (forest, bare ground, residential/other development) and a decrease in agricultural land use (pasture/grassland and cultivated areas) observed after the creation of water reservoirs.

According to Woldemichael et al. (2012), most of anthropogenic changes around dams are prominent once the dam becomes functional and it is previous to investigate the conditions after the dam construction to compare it to the initial undisturbed conditions before (pre-dam) in terms of LULC changes. Vandeveer, Drummond (1976) argue that the difficulty in comparing changes in land use before and after creation of reservoirs is in distinguishing the land use changes associated with reservoir creation from land use changes associated with changing economic conditions and other factors. The problem is finding a comparable area similar in all respects but without the presence of a reservoir; and with the assumption that the difference in land use between the two areas is solely due to reservoir creation. The authors argue that an accurate estimation of the impact of reservoir creation requires the determination of differential land use change which is identified by comparing the projected land uses had the reservoir not been constructed with the actual land uses following the reservoir creation. Pre-investment patterns of land use change are used to project land use patterns that would have existed in the future if the reservoir had not been constructed.

The main aim of this paper is a temporary and spatial analysis of the changes in land use in two Carpathian valleys, with and without dam reservoir. The paper presents the changes of land use in the neighbouring valleys of the Carpathians, with similar natural conditions. This analysis compares the land use in parts of the Biała river and the Ropa river valleys in the years 1977-2009.

Land development in the Biała river valley took place in a natural, evolutionary manner during this period. However, in the Ropa river valley construction of a dam for the retention reservoir started in 1975 to be completed in 1994. This disrupted the natural evolution of the development of this valley. The analysis of land use in both valleys were based on aerial photographs and orthophotomaps.

\section{Study area}

The study area is situated in southern Poland, within the Carpathians, close to the

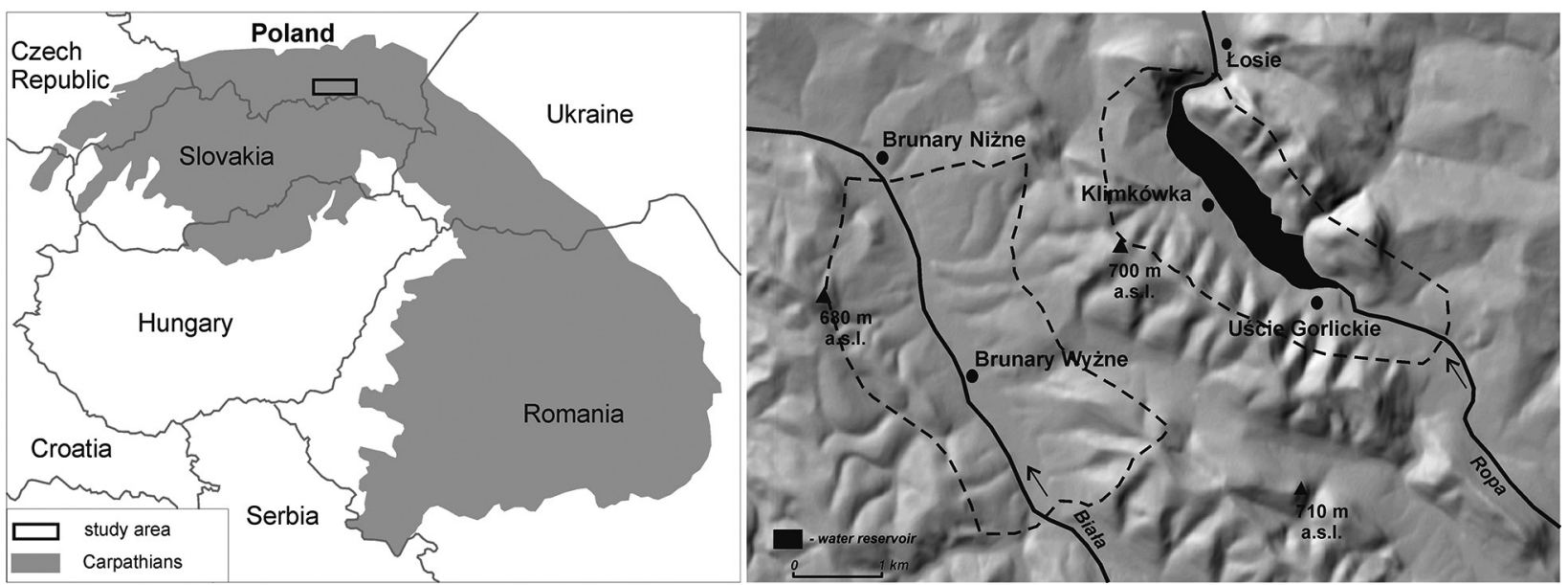

Fig. 1. Study area. 

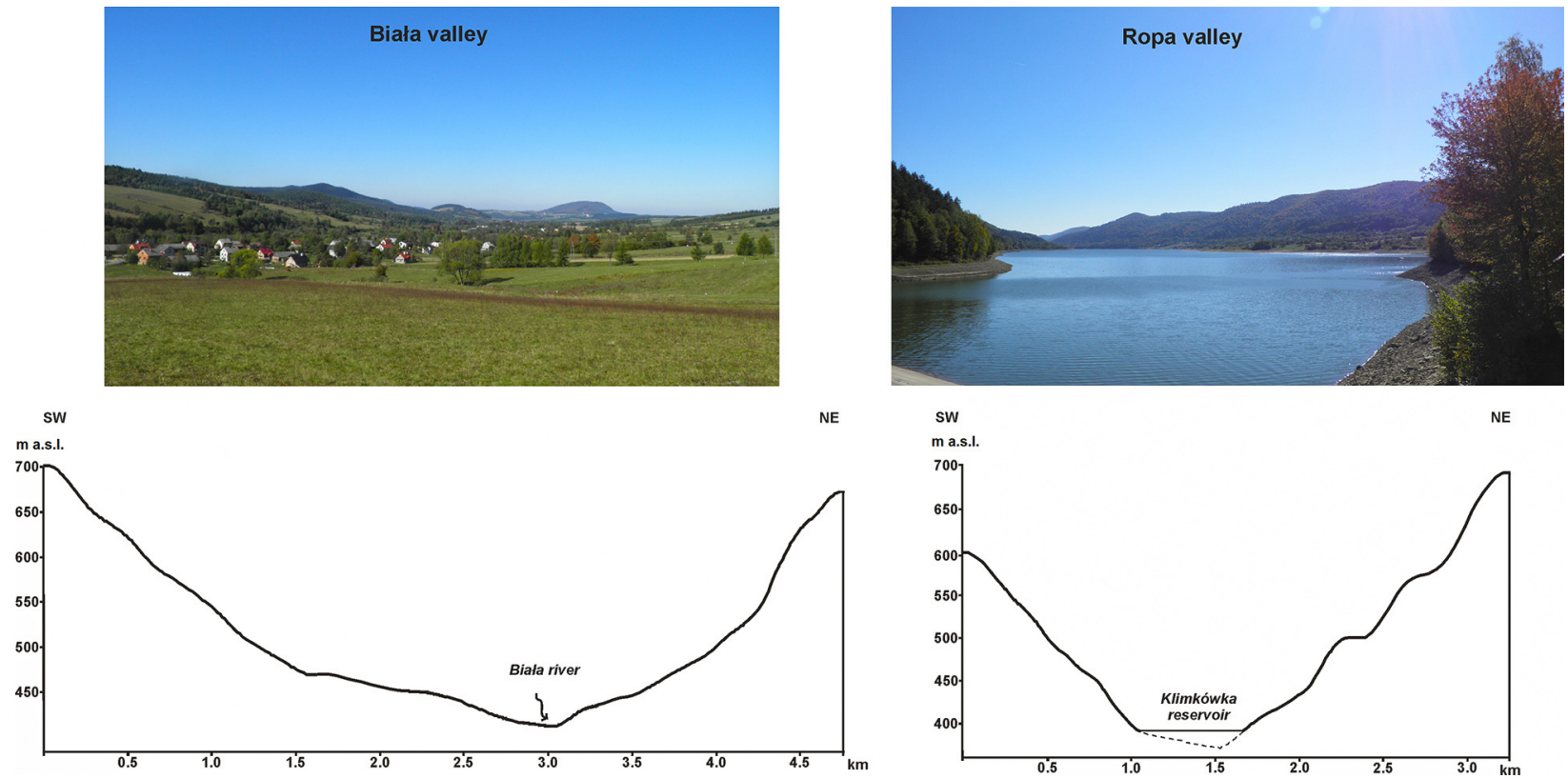

Fig. 2. Cross-sectional profile of the Biała and Ropa valleys (including the Klimkówka reservoir) in the tested areas.

Polish-Slovakian border (Fig. 1). The study involved two selected parts of the neighbouring river valleys: Ropa and Biała. Both rivers are located in the upper basin of the Vistula. The Ropa river is a left-bank tributary of the Wisłoka river, and the Biała river is a right-bank tributary of the Dunajec river. The rivers originate at an altitude of approx. $800 \mathrm{~m}$ above sea level and in the initial run flow within the Beskid Niski Mountains forming a transition area between the Western and the Eastern Carpathians.

The Beskid Niski Mountains study area is located within the Magura nappe. The Magura series is built of tertiary inoceram formations (shale and sandstone) that are resistant to weathering and Magura shale, sandstone and marl forming the highest ridges (Starkel 1972). The study area is located within two vertically-differentiated climatic zones separated by the isotherm $6^{\circ} \mathrm{C}$ : 1) a temperate warm zone, on average, reaching a height of $570 \mathrm{~m}$ a.s.l., and 2) a temperate cold zone, occupying the higher parts of the mountains (Hess et al. 1977).

The study area in the upper part of the Biała river, with a length of $6.6 \mathrm{~km}$, is located in the villages of Brunary Wyżne and Brunary Niżne (in the commune of Uście Gorlickie). The selected area, similarly to the Ropa valley is bounded on the SW and the NE with a watershed and covers $17.2 \mathrm{~km}^{2}$. The Biała river valley altitudes in the selected area are $400-710 \mathrm{~m}$ a.s.l. The width of the valley floor stretches to $1500 \mathrm{~m}$ (Fig. 2). The slopes are inclined at $10^{\circ}$ and they occupy as much as $74 \%$ of the study area (Fig. 3). The study area in the valley of the Ropa river with a length of approx. $7 \mathrm{~km}$ is mainly located within the Klimkówka village (the commune of Ropa) and marginally within Uście Gorlickie and Łosie villages. The selected area is bounded on the SW and the NE with a watershed and covers an area of $15.5 \mathrm{~km}^{2}$. The Ropa valley, is asymmetrical at the reservoir location, with gorges at some points. The Ropa valley altitudes in the selected area reach from 370 to $700 \mathrm{~m}$ a.s.l. (Fig. 2). Slopes with an inclination up to $10^{\circ}$ and in the range of $15-30^{\circ}$ are dominant; they occupy respectively $47 \%$ and $36 \%$ of the area (Fig. 3). The villages of Klimkówka (originally within the areas now

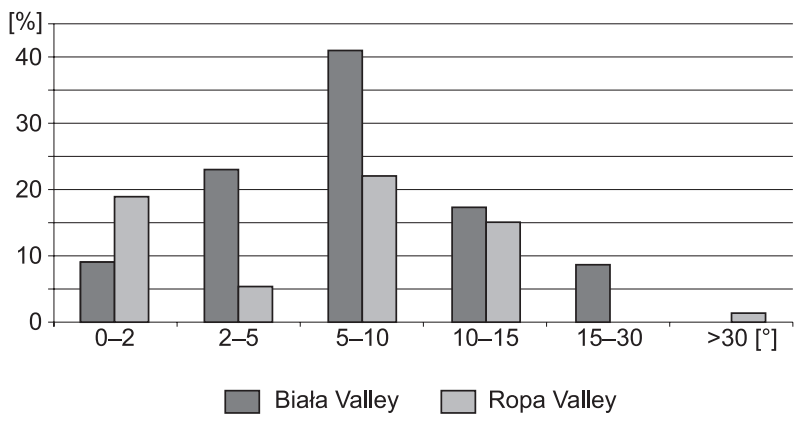

Fig. 3. Slope gradient intervals in the Biała and Ropa valleys ( $\%$ of the tested area). 
occupied by the reservoir) and Brunary Wyżne and Niżne were founded on the Wallachian law with a distinctive forest-strip system of agricultural lands.

According to the census of 1978, there were 627 inhabitants in Brunary, and 874 inhabitants in 2009. In Klimkówka (at the original location) in 1978, the village was inhabited by 213 people, and by 319 people in 2009 (at the new location). In the commune of Uście Gorlickie in 1978, 62\% of the population made their living from agriculture, and in 2009 only $32 \%$, while in the commune of Ropa, in 1978 and 2009, respectively, $53 \%$ and $19.5 \%$ of the population made their living from agriculture (the National Agricultural Census of 1978, the data source: the commune office Uście Gorlickie and the commune office of Ropa).

Hennig (2000) gives that the concept of building a multipurpose reservoir at Klimkówka dates back to the 1960s. The main aim of its construction was to compensate for the Ropa flow by raising the low flows to eliminate the deficits of drinking and industrial water and to lower the maximum height of flood waves along the river. Field work aimed at preparing the ground for future investment started in 1971. The land intended for the creation of the reservoir was mostly private property. A total of $4.72 \mathrm{~km}^{2}$ of land was expropriated and the area was earmarked for the creation of the reservoir and the infrastructure acting as the site. Work connected with the construction of the dam started in April 1975. The Klimkówka reservoir was started in 1994. The Klimkówka reservoir dam crown, with a height of $33 \mathrm{~m}$ and a length of $210 \mathrm{~m}$, was located at the $54.4 \mathrm{~km}$ of the course of the river, about $20 \mathrm{~km}$ south of Gorlice. The maximum depth of the reservoir reaches 30 meters, it's length is approx. $5 \mathrm{~km}$, the width ranges from $200 \mathrm{~m}$ to $800 \mathrm{~m}$ and the maximum area is $3.06 \mathrm{~km}^{2}$. The reservoir enables the production of electricity by means of a hydroelectric power station with a capacity of 1 MW located at the reservoir dam which also has a recreational function. The conducted study shows that local communities, both downstream and upstream from the reservoir, have accepted its presence in the immediate vicinity of their homes (Wiejaczka et al., 2014).

\section{Material and methods}

An analysis of land use changes in the selected research areas located in the Ropa and Biała river valleys was carried out for the years 1977 and 2009 using archival aerial photographs. The changes in land use and land cover (LULC) were derived from panchromatic aerial photos at a scale of 1:16,000 for the year 1977, and colour aerial orthophotomaps on a scale of 1:5,000 for the year 2009. Geometric corrections were performed to rectify all the maps and images using the Transverse Mercator projection system in a GIS ILWIS 3.3 environment (International Institute for Aerospace Survey and Earth Science 1997). In order to standardize the values of the maps from two different time periods, six consistent LULC categories were defined: forest, grassland (meadows and pastures), arable land, road, built-up area and river/reservoir.

A Digital Elevation Model (DEM) was used with spatial resolution of $20 \mathrm{~m}$. The DEM served to generate derivative maps of the proportion of LULC in relation to the slope inclination. According to the developed DEM, the area occupied by the reservoir is in the range of $0-2^{\circ}$ slopes and its maximum range is at an altitude of 400 $\mathrm{m}$ a.s.l. In addition, using GIS techniques, areas used in the same manner in 1997 and 2009 were determined, and are characterized by a change in land use.

\section{Results and discussion}

\section{The structure of land use in the valleys of the Biała and Ropa rivers in 1977}

In 1977, in the Biała river valley, the arrangement of buildings and the configuration of each field indicated the type of forest and agricultural land associated with the village being founded on the Wallachian law (1435). Individual fields departed from the main road running along the valley floor and were overgrown with patches of forest in the upper parts of the slopes, stretching to the watershed. The valley was a rural area, where half of the land i.e. $48.8 \%$ was occupied by agriculture (including arable land 21.5\%), while forests accounted for $47.1 \%$ (Table 1, Fig. 4). Arable land stretched expansively from the main 
Table 1. Land use in the tested area of the Biała and Ropa valley in 1977.

\begin{tabular}{|l|c|c|c|c|}
\hline \multirow{2}{*}{\multicolumn{1}{|c|}{ Land use }} & \multicolumn{2}{|c|}{ Biała valley 1977 } & \multicolumn{2}{c|}{ Ropa valley 1977 } \\
\cline { 2 - 5 } & $\mathrm{km}^{2}$ & \% of area & $\mathrm{km}^{2}$ & \% of area \\
\hline Forest & 8.1 & 47.1 & 10.5 & 67.7 \\
\hline Grassland & 4.7 & 27.3 & 3.4 & 21.9 \\
\hline Arable land & 3.7 & 21.5 & 0.6 & 3.9 \\
\hline Built-up area & 0.2 & 1.2 & 0.6 & 3.9 \\
\hline Roads & 0.2 & 1.2 & 0.3 & 1.9 \\
\hline River/reservoir & 0.3 & 1.7 & 0.1 & 0.7 \\
\hline Total & 17.2 & 100 & 15.5 & 100 \\
\hline
\end{tabular}

buildings in the valley up to the ridges of the mountain. The areas directly related to the settlement (built-up area, roads) were located mainly on the bottom of the Biała valley and occupied $2.4 \%$ of it. The total length of the road network in 1977 in the relevant study area was $15.0 \mathrm{~km}$. On average, there was $0.9 \mathrm{~km}$ of roads per square kilometre.

Within the village of Klimkówka located in the Ropa valley, as in the valley of the Biała river, a strip configuration of the fields was evident. In 1977, forest dominated in the structure of land use $(67.7 \%)$; it grew on the upper part of the slopes above the floor of the Ropa river valley, forming a continuous complex. The presence of the continuous forest complex was mainly conditioned by the steep slopes founded on resistant Magura sandstones (Table 1, Fig. 5). Farmland occupied $25.8 \%$ of the study area. Arable land with an area of $3.9 \%$ occurred almost exclusively on the bottom of the river valley. The bottom of the valley and the higher parts of the slopes were also covered by grassland in the form of meadows, pastures and orchards (21.9\%). Builtup areas, roads and river occupied respectively $3.9 \%, 1.9 \%$ and $0.7 \%$ of the surveyed area of the valley. The total length of the roads within the study area of the Ropa valley was 22.3 kilometres (roads were mainly on the bottom or the lower parts of the slopes of the Ropa river valley). On average, there was $1.44 \mathrm{~km}$ of roads per square kilometre.

\section{The structure of land use in the valleys of the Biała and Ropa rivers in 2009}

In 2009, in the Biała river valley, similarly to 1977, almost half of the area was occupied by farmland $(46.5 \%)$. As compared to 1977 , there was a decrease in arable land of $27 \%$, with a slight increase in grassland from $27.3 \%$ to $30.8 \%$. Arable

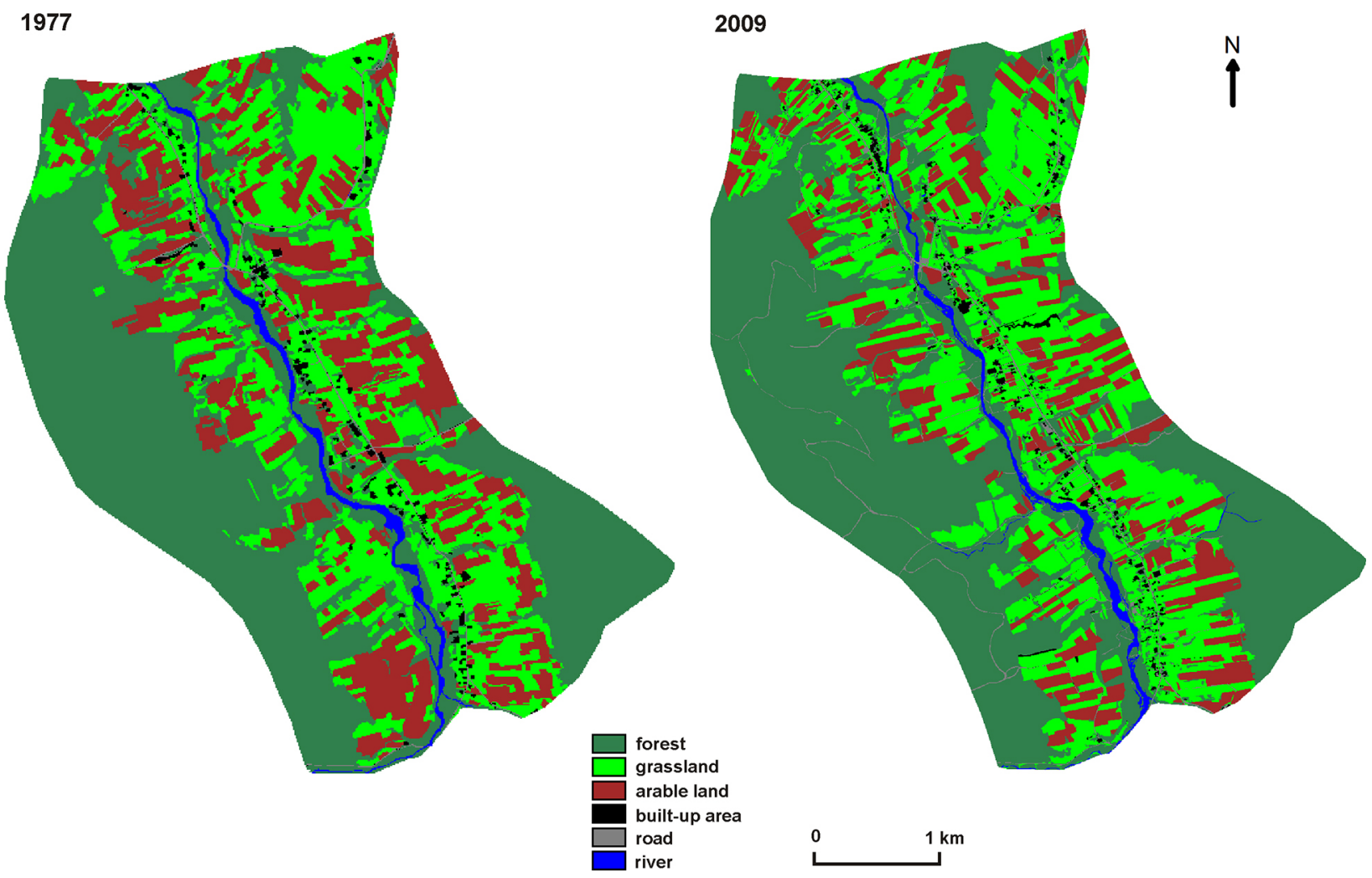

Fig. 4. Land use in the Biała river valley in 1977 and 2009. 

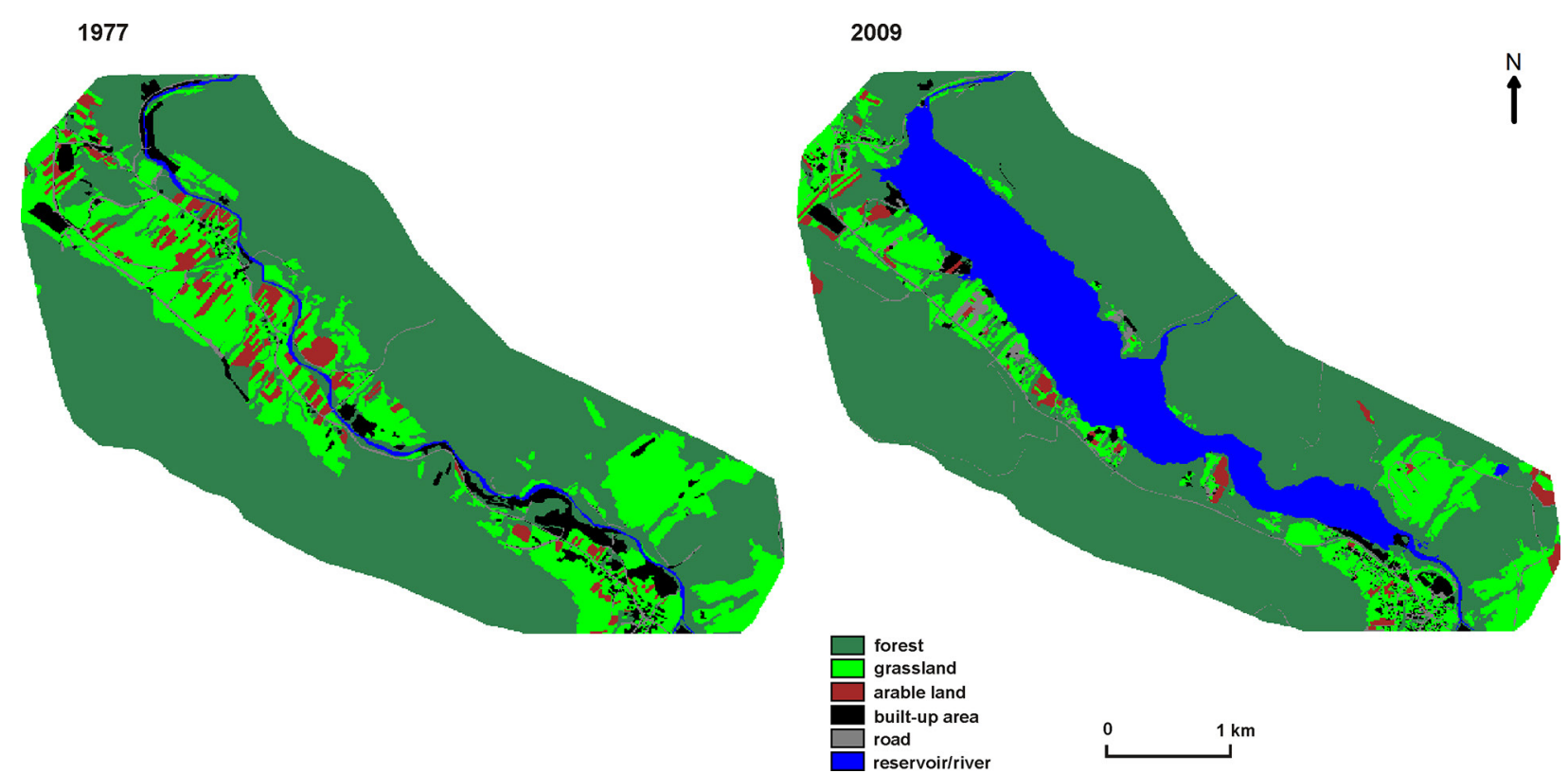

Fig. 5. Land use in the Ropa river valley in 1977 and 2009.

land still stretched from the bottom of the valley to the slopes of the ridges. A slight increase in forest area and areas related to settlements was also noted (Table 2, Fig. 4). Built-up area were distributed evenly, mainly on the valley floor, along the main road running through the villages. The total length of the road network in 2009 increased to $59.0 \mathrm{~km}$, and its density to $3.4 \mathrm{~km} \cdot \mathrm{km}^{-2}$.

The analysis of land use changes in the valley of the Biała river in the studied time period (between 1977 and 2009) with respect to the surface of the designated area showed that $42.8 \%$ of forest, $16 \%$ of grassland and $7.4 \%$ of arable land are stable land (without changes). Over $13 \%$ of arable land was occupied by grassland and forest, and $2.6 \%$ and $6.5 \%$ of grassland, respectively, was overgrown with forest or was converted to arable land (Table 3).

In the valley of the Ropa river, 2009, as compared to 1977, showed a decrease in the forest

Table 2. Land use in the tested area of the Biała and Ropa valley in 2009.

\begin{tabular}{|l|r|c|r|c|}
\hline \multirow{2}{*}{\multicolumn{1}{|c|}{ Land use }} & \multicolumn{2}{|c|}{$\begin{array}{c}\text { Biała valley } \\
\text { \% }\end{array}$} & \multicolumn{2}{c|}{$\begin{array}{c}c \mid \\
\text { 2009 valley }\end{array}$} \\
\cline { 2 - 5 } & $\mathrm{km}^{2}$ & \% of area & $\mathrm{km}^{2}$ & $\%$ of area \\
\hline Forest & 8.4 & 48.8 & 10.1 & 65.2 \\
\hline Grassland & 5.3 & 30.8 & 1.9 & 12.3 \\
\hline Arable land & 2.7 & 15.7 & 0.3 & 1.9 \\
\hline Built-up area & 0.2 & 1.3 & 0.4 & 2.6 \\
\hline Road & 0.3 & 1.7 & 0.3 & 1.9 \\
\hline River/reservoir & 0.3 & 1.7 & 2.5 & 16.1 \\
\hline Total & 17.2 & 100.0 & 15.5 & 100.0 \\
\hline
\end{tabular}

area about $2.5 \%$, which is mainly a consequence of deforestation at the bottom of the Ropa river valley (up to $396 \mathrm{~m}$ a.s.l.) during the creation of the Klimkówka reservoir. Above the valley floor level at an altitude of $400 \mathrm{~m}$ a.s.l. (determined on the basis of the DEM, there was an increase in forest area). Grassland was reduced by more than $43 \%$ (Table 2, Fig. 5), which is, on the one hand, due to the flooding of the valley floor

Table 3. Directions of land use changes (taking into account only $>0.5 \%$ changes of the total surface of the tested area.

\begin{tabular}{|l|c|c|}
\hline \multirow{2}{*}{\multicolumn{1}{|c|}{ Land use changes }} & $\begin{array}{c}\text { Biała valley } \\
1977-2009\end{array}$ & $\begin{array}{c}\text { Ropa valley } \\
1977-2009\end{array}$ \\
\cline { 2 - 3 } & \multicolumn{2}{|c|}{$\%$ of area } \\
\hline Without changes & 66.2 & 68.1 \\
\hline Forest $\rightarrow$ grassland & 2.8 & 1.5 \\
\hline Forest $\rightarrow$ arable land & 0.9 & 0.6 \\
\hline Forest $\rightarrow$ road & 0.7 & 0.7 \\
\hline Forest $\rightarrow$ reservoir/river & - & 5.5 \\
\hline Grassland $\rightarrow$ forest & 2.6 & 3.4 \\
\hline $\begin{array}{l}\text { Grassland } \rightarrow \text { reservoir/ } \\
\text { river }\end{array}$ & - & 6.4 \\
\hline Grassland $\rightarrow$ arable land & 6.5 & 0.7 \\
\hline Arable land $\rightarrow$ forest & 1.5 & - \\
\hline Arable land $\rightarrow$ grassland & 11.7 & 0.7 \\
\hline $\begin{array}{l}\text { Arable land } \rightarrow \text { reservoir } / \\
\text { river }\end{array}$ & - & 1.8 \\
\hline $\begin{array}{l}\text { Build-up area } \rightarrow \text { reservoir } \\
\text { river }\end{array}$ & - & 1.8 \\
\hline Road $\rightarrow$ reservoir/river & - & 0.6 \\
\hline $\begin{array}{l}\text { The area occupied by the } \\
\text { reservoir }\end{array}$ & - & 16.1 \\
\hline
\end{tabular}


(6.4\%), but also from succession to natural forest in the higher parts of the slopes (3.4\%). More than half of the arable land that existed on the Ropa valley floor was flooded as a result of the commissioning of the reservoir (Table 3). During the 1977 to 2009 period the study of land use change revealed that stable land use (without changes) dominates, covering approx. $68 \%$. In addition, approx. $3.4 \%$ of grassland was overgrown with forest through a natural succession, and approx. $1 \%$ of arable land was occupied by grassland and forest. Creation of the reservoir meant that more than $16 \%$ of the total area of forests, grassland, arable land, built-up area and roads was submerged by the reservoir (Table 3).

The creation of the reservoir and the development of settlements on the area adjacent to the reservoir, contributed to the construction of new roads in the higher parts of the slopes of the Ropa river valley. The total length of the road network in 2009 increased to $38.1 \mathrm{~km}$, and its density increased to $2.45 \mathrm{~km}^{-2} \mathrm{~km}^{-2}$ as compared to 1977 . The creation of the body of water caused the development of housing around the reservoir, mainly within the Klimkówka village, on the left less inclined slope of the Ropa river valley. In the higher parts of the slope, on the right side of the valleys, where there were no buildings before the reservoir was created, scattered buildings appeared. Summer residences also started to be built next to residential houses in the valley. Therefore, the function of the buildings in the study area changed, from residential and agricultural to residential and recreational. Compact building, as in 1977, was concentrated mainly in Uście Gorlickie village, adjacent to the study area.

\section{Changes in the structure of land use in the valleys' slope intervals between 1977 and 2009}

In the analysed period, a decrease in the share of arable land in all slope gradient intervals was observed in the Biała river valley. The largest decrease in arable land, by more than $40 \%$, as compared to that of 1977, occurred on the slopes of $15-30^{\circ}$ inclination. The area of forest and grassland increased in almost all slope gradient intervals, with the largest increase in the area of grassland in the range of $15-30^{\circ}$ slopes, by approximately $33 \%$ and area of forest in the range of $2-5^{\circ}$ about $12 \%$ The bottom of the Biała valley is an exception $\left(0-2^{\circ}\right)$; the decrease in the share of the forest area recorded there was by about $19 \%$ (Table 4), which can be associated with an increase in the area of grassland, built-up area and roads. Changes in the structure of land use which progressed gradually in the Biała river valley, are the result of the socio-economic transformations, resulting from the intensified political and social transformation of the country after 1989. The confirmation of these observed changes is the reduced share of people who earn their living from agriculture which almost halved in 2009, as compared to 1978 (according to a general population census). Similar changes occurred throughout the Western Carpathians (Kozak 2003, Ostafin 2009, Bucała 2014, Bucała-Hrabia 2017).

In the Ropa river valley, within the slope inclinations in the range of $0-2^{\circ}$, there was a decrease of arable land by $95 \%$; such a large decrease should be associated with the creation of the Klimkówka reservoir at the bottom of the Ropa valley. In turn, on $5-10^{\circ}$ slopes, there was an increase arable land more then $100 \%$, as compared to 1977, which was connected with the transfer of arable lands from the bottom of the Ropa valley

Table 4. The share of forest, grassland and arable land in the designated slope gradient intervals in the Biała and Ropa river valleys.

\begin{tabular}{|c|c|c|c|c|}
\hline \multirow{2}{*}{ Slope gradient intervals $\left({ }^{\circ}\right)$} & \multicolumn{2}{|c|}{ Biała valley } & \multicolumn{2}{|c|}{ Ropa valley } \\
\hline & 1977 & 2009 & 1977 & 2009 \\
\hline \multicolumn{5}{|c|}{ forest (\% of area) } \\
\hline $0-2$ & 4.1 & 3.3 & 4.7 & 1.2 \\
\hline $2-5$ & 6.4 & 7.2 & 2.3 & 2.1 \\
\hline $5-10$ & 16.2 & 16.6 & 10.9 & 11.2 \\
\hline $10-15$ & 12.3 & 13.5 & 12.8 & 13.4 \\
\hline $15-30$ & 8.1 & 8.2 & 35.5 & 35.6 \\
\hline$>30$ & - & - & 1.5 & 1.7 \\
\hline \multicolumn{5}{|c|}{ grassland (\% of area) } \\
\hline $0-2$ & 2.1 & 2.5 & 7.5 & 1.5 \\
\hline $2-5$ & 9.2 & 10.4 & 1.9 & 1.4 \\
\hline $5-10$ & 13.2 & 14.7 & 9.7 & 7.8 \\
\hline $10-15$ & 2.5 & 2.8 & 2 & 1.2 \\
\hline $15-30$ & 0.3 & 0.4 & 0.8 & 0.4 \\
\hline$>30$ & - & - & - & - \\
\hline \multicolumn{5}{|c|}{ arable land (\% of area) } \\
\hline $0-2$ & 1.3 & 1.0 & 2.3 & 0.1 \\
\hline $2-5$ & 5.9 & 4.2 & 0.7 & 0.3 \\
\hline $5-10$ & 11.3 & 8.5 & 0.6 & 1.4 \\
\hline $10-15$ & 2.5 & 1.7 & 0.2 & 0.1 \\
\hline $15-30$ & 0.5 & 0.3 & 0.1 & 0.0 \\
\hline$>30$ & - & - & - & - \\
\hline
\end{tabular}


to higher parts of the slopes. On the slopes above $10^{\circ}$, arable land decreased by $50 \%$, which is likely to be connected to the uneconomic use of the land on the steep slopes (Table 4). The creation of the reservoir also had the effect of reducing the share of grassland and forest by, respectively, $80 \%$ and $75 \%$ on the bottom of the Ropa valley $\left(0-2^{\circ}\right)$. Along with the increasing inclination of the slopes inclination of the slope above $2^{\circ}$, there was a decline in the share of grasslands, on average by $35 \%$, and a slight increase in forest area by approx. $6 \%$.

\section{Conclusions}

The analysis land use changes in two Carpathians valleys in the period 1977-2009 showed the following regularities:

Changes in land use occurring in the Biała river valley in the 30-year period in question are especially in the areas at higher altitudes and on steep slopes; grasslands (11.7\%) and forest (1.5\%) areas emerged in place of arable land. In both 1977 and in 2009, about $66 \%$ of the study area was used in the same manner, and the overall structure is still dominated by agricultural land, which constitutes $46.5 \%$ of the study area.

The changes in land use occurring in the Ropa river valley in the same time period are more visible, i.e. decrease of arable land by $50 \%$ (on the slopes with an inclination of more than $15^{\circ}$ ). A very clear determinant of the direction and the scale of changes is the creation and operation of the reservoir. The most important effects of the creation of the reservoir include: loss of the forest area by $5.5 \%$ and farmland by $8.2 \%$ on the areas submerged by reservoir, the increase arable land more than $100 \%$, as compared to 1977 on slopes inclined by $5-10^{\circ}$ (which is related to the forced relocation of arable lands, due to the formation of the reservoir, from the bottom of the Ropa river valley to the higher parts of the slopes), a decrease of grassland by $35 \%$ on the slopes inclined above $2^{\circ}$.

The following can be distinguished among the other effects of the reservoir creation: arrangement of agricultural lands changed from the strip pattern to a more dispersed one, the road and construction network changed (buildings together with a network of new roads on the slopes), the nature of the buildings in the Ropa river valley changed from residential and agricultural to residential and recreational.

It should be noted that the general directions of the transformation in both valleys in the structure of land use are similar. A decrease in the share of agricultural land is observed, especially on steep slopes.

\section{References}

Bätzing W., Perlik M., Dekleva M., 1996. Urbanization and depopulation in the Alps. Mountain Research and Development 16: 335-350. doi: 10.2307/3673985.

Bucała A., 2014. The impact of human activities on land use and land cover changes and environmental processes in the Gorce Mountains (Western Polish Carpathians) in the past 50 years. Journal of Environmental Management 138: 4-14. doi: 10.1016/j.jenvman.2014.01.036.

Bucała A., Budek A., Kozak M., 2015. The impact of land use and land cover changes on soil properties and plant communities in the Gorce Mountains (Western Polish Carpathians), during the past 50 years. Zeitschrift fur Geomorphologie, 59(2): 41-74. doi: http://dx.doi.org/10.1127/ zfg_suppl/2015/S-59204.

Bucała-Hrabia, A., 2017. From communism to a free-market economy - a reflection on economic changes in land use in the vicinity of the city of Beskid Sądecki (Western Polish Carpathians). Geographia Polonica 90(1): 65-79. doi: https://doi.org/10.7163/GPol.00xx.

Cao Y., Zhou W., Wang J., Yuan C., 2011. Spatial-temporal pattern and differences of land use changes in the Three Gorges Reservoir Area of China during 1975-2005. Journal of Mountain Science 8(4): 551-563. doi: 10.1007/s11629011-2008-8.

Dec M., Kaszta Ż., Korzeniowska K., Podsada A., Sobczyszyn-Żmudź S., Wójtowicz A., ... \& Ostapowicz K., 2009. Zmiany użytkowania ziemi w trzech gminach karpackich (Niedźwiedź, Szczawnica i Trzciana) w drugiej połowie XX wieku. Archiwum Fotogrametrii, Kartografii $i$ Teledetekcji 20: 81-98.

Falcucci A., Maiorano L., Boitani L., 2007. Changes in landuse/land-cover patterns in Italy and their implications for biodiversity conservation. Landscape Ecology 22(4): 617-631. doi: 10.1007/s10980-006-9056-4.

Graf W. L., 2006. Downstream hydrologic and geomorphic effects of large dams on American rivers. Geomorphology 79(3): 336-360. doi: 10.1016/j.geomorph.2006.06.022.

Hennig J., 2000. Historia zbiornika Klimkówka. In: Łagosz T. (eds), Zbiornik wodny Klimkówka Monografia, IMGW, Warszawa: 27-32.

Hess M., Niedźwiedź T., Obrębska-Starklowa B., 1977. Stosunki termiczne Beskidu Niskiego. Prace Geograficzne IGIPZ PAN 123.

Kaim D., 2009. Zmiany pokrycia terenu na pograniczu polsko-słowackim na przykładzie Małych Pienin= Land-cover changes in Polish-Slovakian border regions: a case study of the Małe Pieniny Mts. Przeglad Geograficzny 81(1): 93-106.

Kijowska-Strugała M., 2015. Transport zawiesiny w warunkach zmieniającej się antropopresji w zlewni Bystrzanki (Karpaty Fliszowe). Prace Geograficzne IGiPZ PAN 247. 
Kijowska-Strugała M., Demczuk P., 2015. Impact of land use changes on soil erosion and deposition in a small Polish Carpathians catchment in the last 40 years. Carpathian Journal of Earth and Environmental Sciences 10(2): 261-270.

Kozak J., 2003. Forest cover change in the Western Carpathians in the past 180 years, A case study in the Orawa region in Poland. Mountain Research and Development 23(4): 369-375. doi: http:/ / dx.doi.org/10.1659/0276-4741(2003 )023[0369:FCCITW]2.0.CO;2.

Lipský Z., 2001. Present land use changes in the Czech cultural landscape: driving forces and environmental consequences. Moravian Geographical Reports 9(2): 2-14.

MacDonald D., Crabtree J. R., Wiesinger G., Dax T., Stamou N., Fleury P., Gutierrez Lazpita J., Gibon A., 2000. Agricultural abandonment in mountain areas of Europe: Environmental consequences and policy response. Journal of Environmental Management 59(1): 7-69. doi: 10.1006/ jema.1999.0335.

Magilligan F J., Nislow K. H., 2005. Changes in hydrologic regime by dams. Geomorphology 71(1): 61-78. doi: 10.1016/j. geomorph.2004.08.017.

Nilsson C., Berggren K., 2000. Alterations of Riparian Ecosystems Caused by River Regulation Dam operations have caused global-scale ecological changes in riparian ecosystems. How to protect river environments and human needs of rivers remains one of the most important questions of our time. BioScience 50(9): 783-792.

Ostafin K., 2009. Zmiany granicy rolno-leśnej w środkowej części Beskidu Średniego od połowy XIX wieku do 2005 roku. Wydawnictwo Uniwersytetu Jagiellońskiego, Kraków.

Petts G. E., Gurnell A. M., 2005. Dams and geomorphology: research progress and future directions. Geomorphology 71(1): 27-47. doi: 10.1016/j.geomorph.2004.02.015.

Pilgrim C., 2014. Spatial and temporal analysis of land cover change, sedimentation and water quality in the Lake Issaqueena watershed, South Carolina.
Power M. E., Dietrich W. E, Finlay J. C., 1996. Dams and downstream aquatic biodiversity: potential food web consequences of hydrologic and geomorphic change. Environmental management 20(6): 887-895. doi: 10.1007/ BF01205969.

Soja R., Wiejaczka Ł., 2014. The impact of a reservoir on the physicochemical properties of water in a mountain river. Water and Environment Journal 28(4): 473-482. doi: 10.1111/wej.12059.

Starkel L., 1972. Zachodnie Karpaty Zewnętrzne (fliszowe). In: Klimaszewski M. (eds) Geomorfologia Polski, 1, Warszawa: PWN: 52-115.

Szwagrzyk J., 2004. Sukcesja leśna na gruntach porolnych; stan obecny, prognozy i wątpliwości. Sylwan 4: 53-59.

Tefera B., Sterk G., 2008. Hydropower-induced land use change in Fincha'a watershed, western Ethiopia: Analysis and impacts. Mountain Research and Development 28(1): 72-80. doi: http://dx.doi.org/10.1659/mrd.0811.

Vandeveer L. R., Drummond H. E., 1976. Differential land use change as the result of the construction of the Keystone Reservoir. Proceedings of the Oklahoma Academy of Science 56: 153-158.

Wei G., Yang Z., Cui B., Li B., Chen H., Bai J., Dong S. 2009. Impact of dam construction on water quality and water self-purification capacity of the Lancang River, China. Water resources management 23(9): 1763-1780. doi: 10.1007/s11269-008-9351-8.

Wiejaczka Ł., Piróg D., Soja R., Serwa M., 2014. Community perception of the Klimkówka Reservoir in Poland. International Journal of Water Resources Development 30(4): 649-661. doi: 10.1080/07900627.2014.892426.

Woldemichael A. T., Hossain F., Pielke R., Beltrán-Przekurat A. 2012. Understanding the impact of dam-triggered land use/land cover change on the modification of extreme precipitation. Water Resources Research 48 (9): 1-16. doi: 10.1029/2011WR011684. 